\title{
ヒト腎細胞癌細胞株（KG-2）の樹立とヌードマウスを用いた
}

\author{
ヒト腎細胞癌転移モデルの作成 \\ ${ }^{1)}$ 神戸大学医学部泌尿器科学教室 (主任：守殿貞夫教授) \\ 2) 東京大学応用微生物研究所生物活性（主任：鶴尾 隆教授） \\ 郷司 和男 ${ }^{133}$ 中島 元夫 ${ }^{2)}$ 守殿 貞夫 ${ }^{1)}$
}

\section{ESTABLISHMENT AND CHARACTERIZATION OF A NEW HUMAN RENAL CELL CARCINOMA CELL LINE (KG-2) AND METASTATIC MODEL IN NUDE MICE}

\author{
Kazuo Gohji ${ }^{1)}$, Motowo Nakajima ${ }^{2)}$ and Sadao Kamidono ${ }^{1)}$ \\ ${ }^{1)}$ Department of Urology, Kobe University School of Medicine \\ (Director: S. Kamidono) \\ ${ }^{2)}$ The Institute of Applied Microbiology, The University of Tokyo \\ (Director: T. Tsuruo)
}

A new cultured cell line (KG-2) derived from human renal cell carcinoma and a metastatic model in nude mice were studied. KG-2 was cultured from renal cell carcinoma (clear cell carcinoma) of the left kidney. In vitro doubling time of KG-2 was approximately 50 hours. KG-2 cells produced tumors in both the subcutaneous and renal sub-capsular space in nude mice, with tumorigenicity of $75 \%$, showing no difference between the two sites. Histologically, tumors formed in the subcutaneous sites were hypovascular granular cell carcinoma. Moreover, each tumor was encapsulated by a thick fibrous capsule and never produced distant metastasis or invasion into the surrounding tissue. However, tumors formed in the subrenal capsular space were clear cell carcinoma. These tumors were hypervascular, and produced distant metastases. The most common metastatic site was the lung. Immunohistochemical analysis using anti-human collagenase type IV antibody on tumors formed in subcutaneous and subrenal capsular sites demonstrated that the expression of this enzyme in tumors formed in the subrenal capsular space was much higher than that in tumors formed in the subcutaneous site. Additionally, immunohistochemical study using anti-mouse collagen type IV antibody, a major components of the vascular wall, demonstrated many small densely growing vessels in tumors formed in the subrenal capsular space. In contrast, few vessels were produced in tumors formed in subcutaneous sites. These findings suggest that factors relating to the different injection sites may regulate the production of collagenase type IV secreted by KG-2 cells and neovascularity in nude mice. This metastatic model may be useful in the study of the mechanism of cancer metastases.

Key words: renal cancer, collagenase type IV, metastases

\footnotetext{
要旨：新しくヒト腎細胞癌培養株(KG-2)を樹立すると共に, ヒト腎細胞癌転移動物モデルを作成した。 KG-2細胞は組織型が淡明細胞癌であった摘出左腎腫瘍より樹立され，その in vitro doubling time は約 50時間であった。本腫瘍細胞をヌードマウスの皮下および腎被膜下に移植したところ両者間で造腫瘍能 に差を認めなかった(共に75\%)。しかし，皮下に形成された腫瘍の組織像は顆粒細胞癌で血管に乏しく 線維性被膜に被われ転移浸潤傾向を示さなかった。他方，腎被膜下に形成された腫瘍は淡明細胞癌で腎 実質および同周囲組織へ浸潤傾向を示し，高率に肺に転移をきたした。抗ヒト collagenase type IV 抗
}

3) 現：兵庫県立成人病センター泌尿器科 
体を用いた免疫組織学的検討では，腎被膜下腫瘍では皮下腫瘍に比べ本酵素の発現が強くまた抗マウス collagen type IV 抗体を用いた検討では腎被膜下に形成された腫瘍では，皮下に形成された腫瘍に比べ より密に腫瘍内新生血管の増生が認められた。これらの事実は腫揚細胞移植部位での host 例の何らかの 因子が移植腫瘍の collagenase type IV 産生, おょび腫瘍内新生血管の増生を調節している可能性が示 唆された。

本転移モデルはヒト腎細胞癌の転移機序の解明に有用と思われた。 キーワード：腎細胞癌,コラゲナーゼタイプIV，癌転移

\section{緒 言}

腎細胞癌は, 泌尿器科領域の悪性腫瘍のうち膀胱癌, 前立腺癌に次いで多いが，制癌化学療法，免疫療法拈 上び放射線療法等は有効性にそしく，手術療法のみ有 用とされる。従って遠隔転移を有する進行例の予後は 極めて不良である.

遠隔転移を有する進行期癌に対する有効な治療法の 開発には，癌転移機序解明のために有用な“転移モデ ル”を確立することがその第一歩と思われる。そこで 最近, 我々は新しくヒト腎細胞癌培養株細胞を樹立し, この細胞をヌードマウスの orthotopic site(腎被膜下) に移植することで主に肺転移を形成する“転移モデル” を作成したのでその性状につき報告する。

\section{方法}

\section{1. 培養細胞株の樹立}

根治的左腎摘出術により58歳男性から得られた左腎 細胞癌を無菌的に切除し, 肉眼的に出血巣, 壊死巣を 除去した後,クーパーと,メスを用いて約 $1 \mathrm{~mm}^{3}$ の大き さに細切する。その後 $270 \mathrm{U} / \mathrm{ml}$ の DNase および200 $\mathrm{U} / \mathrm{ml}$ の collagenase type I (共に Sigma Chemical $\mathrm{Co}$, St. Louis, MO）の混合液中で $37^{\circ} \mathrm{C} ， 30$ 分間攪挥 し, 滅菌 4 層ガーゼで濾過した後, 細胞浮遊液を Hank's balanced salt solution (HBSS; GIBCO, Grand Island, NY) で 2 度遠沈 $(\times 1,000 \mathrm{~g}, 5$ 分間), 洗浄する。その後 $10 \%$ fetal bovine serum (FBS), sodium pyruvate, non essential amino acid, Lglutamine 拈よび vitamin solution（いずれも GIBCO, NY) 含む Eagl's minumum essential media (EMEM ; GIBCO, NY) を加光 trypan blue 染 色を施し Coulter Counter (Coulter Electronics Inc. Hialeah，FL.) を用いて非青染細胞を生細胞として数 え $1 \times 10^{5}$ 個 $/ \mathrm{ml}$ の生細胞浮遊液を作成する。こうして 得られた生細胞浮遊液を直径 $60 \mathrm{~mm} の$ tissue culture petri dish (Costar, Cambridge, MA) に播種し, 静 置培養した。培地は72時間毎に新鮮 $10 \% \mathrm{FBS}$ 含有 EMEM と半量交換された。細胞がシート状に増殖し
約 $80 \%$ confluent となったとき,培地を捨て dish を $5 \mathrm{ml}$ の HBSS で軽くす寸いだ後， $0.02 \%$ EDTA と $0.25 \%$ trypsin (共に SIGMA ; NY) 混合液 $5 \mathrm{ml}$ を数分間作用 させ，軽くピペッティングを施行した後， $20 \mathrm{ml} の 10 \%$ FBS 含有 EMEM 中で 2 度遠沈 $(\times 1,000 \mathrm{~g}, 5$ 分間), 洗浄した. trypan blue 染色を施し生細胞数をかぞ兄 $5 \times 10^{5}$ 個の生細胞を直径 $60 \mathrm{~mm}$ の tissue culture petri dish に播種し, $37^{\circ} \mathrm{C} て ゙$ 再び培養を続けた。な打摘 出腎細胞癌の組織型は日本泌尿器科学会編, 腎癌取り 扱い規約 ${ }^{1}$ に準じ clear cell common type, grade 2(図 1), pT2, V (0), N (0) であった。本腫瘍は術後約 1 年目に肺および骨に多発性転移をきたした。

2. 細胞倍化時間

$1 \times 10^{4}$ 個の生細胞を直径 $35 \mathrm{~mm}$ の tissue culture petri dish (Costar, MA) 播種し, $2 \mathrm{ml} の 10 \% \mathrm{FBS}$ 含有 $\mathrm{EMEM}$ 中で培養した。培養開始後 24 時間毎に 7 日間，細胞に0.02\%EDTA と $0.25 \%$ trypsin の混合液 を数分間作用させた後, 軽くピペッティングを施し単 離細胞浮遊液を作成し, 前述したのと同様に trypan blue 染色を施して生細胞数を数えた。培養は 3 プレー トずつ行われその平均值をグラフ上に protし, 細胞倍 加時間を算出した。な招培地は 72 時間毎に新鮮 $10 \%$

図 1 原腫瘍の病理組織像: 腫瘍は主に clear cell carcinoma より成る腎細胞癌である ( H \& E 染色 $\times$ 250).

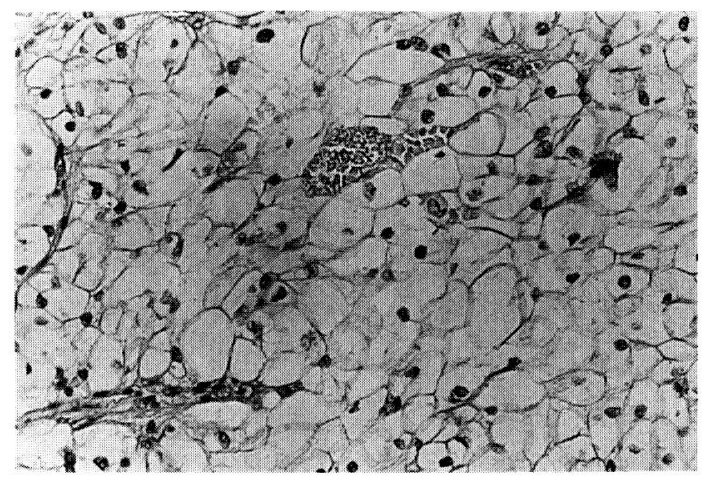


FBS 含有培地と半量交換された。

3. 培養細胞のヌードマウスへの移植

a) 皮下移植

対数增殖期にある第 5 代目培養細胞を $0.02 \%$ EDTA と $0.25 \%$ trypsin の混合液を作用させ単離細胞 浮遊液を作成し， 2 度 HBSS で遠沈，洗浄し trypan blue 染色を施した後非青染細胞を数兄，95\%以上の生 細胞率を有する $5 \times 10^{6}$ 細胞 $/ \mathrm{ml}$ の HBSS 単離細胞浮

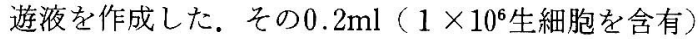
を27G needle 付注射器を用いて 8 週齢, 雄ヌードマウ スの皮下へ移植した。毎週，腫瘍形成の有無および腫 瘍の長径, 短径を測定して下記の数式により腫瘍の推 定体積を求め, グラフ上に plot して腫瘍倍化時間を求 めた。

\section{推定腫瘍体積 $=$ 長径 $\times(\text { 短径 })^{2} / 2$}

腫瘍の長径が約 $2 \mathrm{~cm}$ に達した時ヌードマウスを屠 殺し，摘出皮下腫瘍重量を計測すると共に一部は一 $180^{\circ} \mathrm{C}$ 液体窒素にて凍結, 残りは $10 \%$ ホルマリン溶液に て固定後組織学的検討に用いた。 また全葴器を摘出, $10 \%$ ホルマリン溶液にて固定後転移の有無る確認し。 なお, 肺は24時間 Bouins 溶液にて固定後, 実体顕微鏡 下に值径 $0.1 \mathrm{~mm}$ 以上の転移結節を数えた啳 $10 \%$ ホル マリン固定し，組織学的に検討した。

b）腎被膜下移植

内藤らの方法に準じた ${ }^{2)}$.すなわち 8 週粉雄 ヌード マウスを methoxyflurane で麻酔後, 左季助部をク一 パーで切開し脾蔵を露出，綿棒を用いて脾臓を腹側へ 圧排し左腎を露出する。腎下極より $27 \mathrm{G}$ needle 付注射 器をゆっくり腎上極へむけ刺入し，腎被膜に水疱がで きる様に $1 \times 10^{6}$ 生細胞を含む0.05mlの HBSSを注 入し，周囲へもれのないことを確認後，腎を創内へも どし皮膚をクリップにて閉鎖した。約 3 力月後にマウ スを屠殺解剖し，皮下腫湯と同様に腎被膜下に形成さ れた腫瘍および全臓器を摘出, ホルマリン固定し, 組 織学的検討扣よび転移巣の検索を行った。

4. 免疫組織染色

中島らの方法に準じて行っだ).すなわちヌードマ ウスに形成された腫瘍を摘出し，壊死および出血巣を 取り除いた後, Tissue TEK, O.C.T. Compound(Miles Laboratory, Elkhart, Ind)を充満した直径 $20 \mathrm{~mm} の$ アルミ製容器に腫湯片を入れ, 液体窒素で急速凍結し

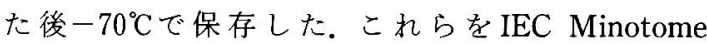
cryostat で薄切し，3-amino propyltriethoxysilane (Aldrich Chemical Co, Inc) でュートしたスライド
ガラス上で $23^{\circ} \mathrm{C} ， 45$ 分間乾燥させた。その後 $0.125 \%$ glutaraldehyde で 2 分間固定し HBSSで軽くすす き，更に1.0\%Triton X-100で 5 分間処理した。次に， phosphate buffered saline (PBS : SIGMA, NY.) で 洗浄後 $1 \%$ goat 血清拈よび $1 \%$ 牛血清をふくさPBS で20分間処理し，次に各抗体を 1 時間反応させた。 そ の後スライドガラスをPBSで 3 度すすぎ，4倍に希 釈した gold-labeled goat anti-rabbit IgG (GAR5; Janssen Life Science Products, Piscataway, NJ) で 1 時間処理し，PBS 拈よび蒸留水で軽く洗った。 れらを Mayer's hematoxylinで対染色を施し, 光学顕 微鏡下に観察した。抗体は72kda および92kda 抗ヒト collagenase type IV 抗体 (National Cancer Institute の Lance A Liotta 博士より供与) 执よび抗マウス collagen type IV 抗体 (Collaborative Res; Bedford, Mass，USA.）を用いた。

\section{結 果}

1. KG-2細胞の形態および in vitro doubling time 本細胞は培養開始当初より殆ど fibroblast の混入, 増殖を認めず，多角形をした大型核を有する細胞が， 単層に増殖し所々に分裂像を有していた(図 2 )。しか し，上皮細胞の単層培養でみられる“敷石状”増殖を 示さず，一見，間葉系由来の細胞の如く個々の細胞は 単離して増殖する様にみ点た。本培養細胞は KG-2 と 命名された。 KG-2細胞の in vitro doubling time は比 較的遅く第 5 代，第 8 代执よび第 15 代の細胞で各 52 , 48 おび40時間であった。

2. ヌードマウスでの腫瘍形成能および転移能

Ectopic site（皮下）および orthotopic site（腎被膜 下）に移植された KG-2細胞の造腫瘍能と転移能を表

図 $2 \mathrm{KG}-2$ 細胞の倒立顕微鏡像：多角形をして大型 核を有する細胞が単層に増殖している $(\times 120)$.

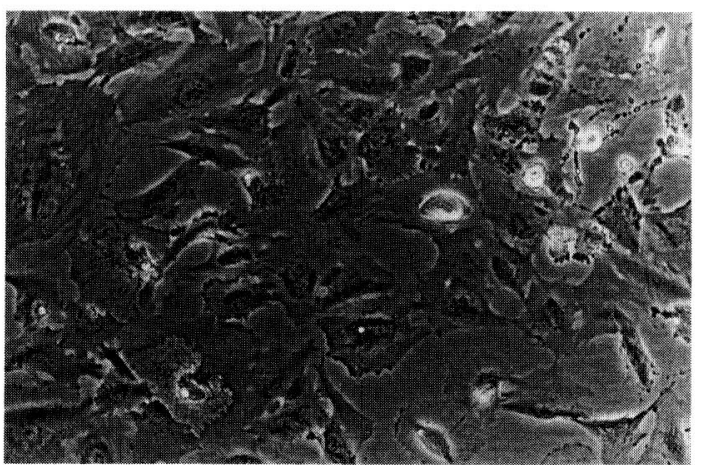


図 3 ヌードマウスに形成された腫瘍の病理像：A） 皮下 (ectopic site) 腫瘍；腫瘍の組織型は granular cell common typeで中心壊死を伴って抢り厚い線 維性被膜でよく被われている（H＆Ｅ染色×120） 矢印; 線維性被膜.

B) 腎被膜下 (orthotopic site) 腫瘍：腫瘍の組織型 は原腫瘍とよく類似した clear cell common type である（H \& E染色 $\times 120 ）$.
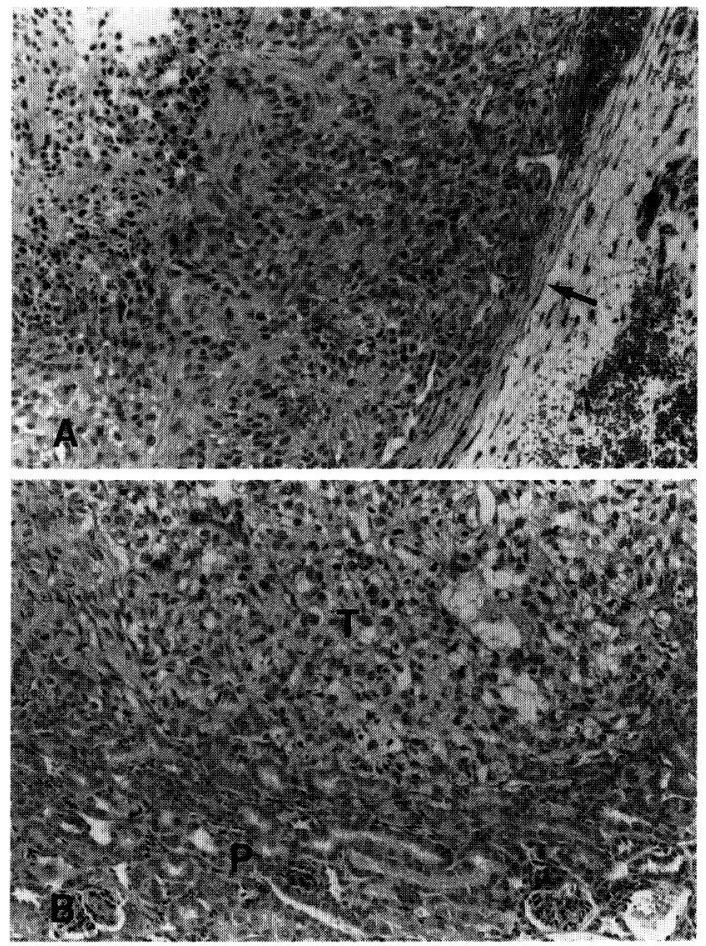

1 に示す. Ectopic 抢よび orthotopic site での造腫瘍 能は共に75\%と両者間に差を認めない.しかし ectopic site に形成された腫瘍は転移浸潤傾向を示さ ないのに対し，orthotopic siteに形成された腫瘍は 75\%の例で遠隔転移をきたした。転移部位で最も多い のは肺，次いで腎茎部リンパ節，腹腔内への直接浸潤 の順であった、また肺転移栄結節数はヌードマウス 1 匹あたり 2 〜0個でその中央值は 9 個であった。

3. ヌードマウスにおける ectopic および orthotopic site に形成された腫瘍の病理組織学的検討

Ectopic 㧍よび orthotopic site に形成された腫瘍の 病理組織学的所見の概略を表 1 に示す.

Ectopic site に形成された腫瘍は病理学的に腎細胞 癌, granular cell common type で原腫瘍の組織型 (clear cell common type) とは異なっており，これら
図 4 抗マウス collagen type IV 抗体を用いたヌー ドマウス腫瘍の免疫組織像：A) 皮下 (ectopic site) 腫瘍；比較的大型の血管が疎に新生している. B) 腎被膜下 (orthotopic site) 腫瘍 ; 小血管が密に 新生している $(\times 100)$.

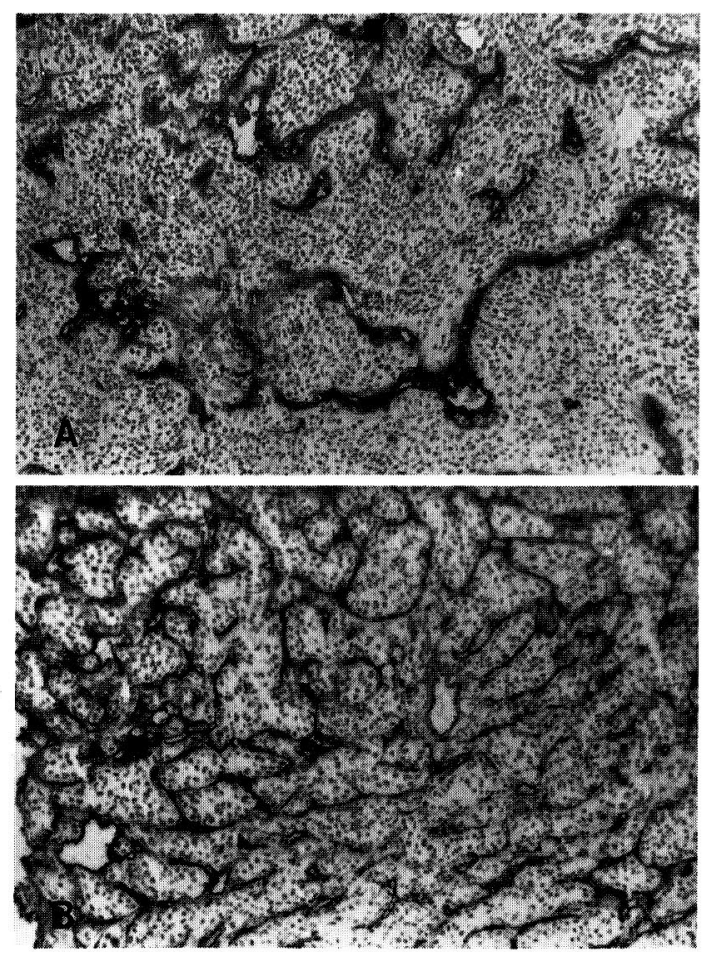

表 1 ヌードマウスにおける KG-2細胞の造腫瘍性, 転 移浸潤能掞よび形成腫瘍の組織像

\begin{tabular}{|c|c|c|}
\hline 移植部位 & $\begin{array}{c}\text { 皮 } \underset{\text { (Ectopic }}{\text { site) }} \\
\text { (Ecto }\end{array}$ & $\begin{array}{c}\text { 腎被膜下 } \\
\text { (Orthotopic site) }\end{array}$ \\
\hline 造腫瘍能 & $9 / 12(75 \%)$ & $12 / 16(75 \%)$ \\
\hline 組織像 & 顆粒細胞癌 & 淡明細胞癌 \\
\hline 被膜 & + & - \\
\hline \multirow[t]{2}{*}{ 腫晹血管新生 } & + & H \\
\hline & 大型の血管が柾に増生 & 小型の血管が密に増生 \\
\hline 中心壊死 & + & - \\
\hline 転移・浸潤能 & $0 / 9(0 \%)$ & $9 / 12(75 \%)$ \\
\hline 肺（転移結節数） & 0 & $9 / 9(2-40 ; 9)^{1)}$ \\
\hline リンパ節 & 0 & $1 / 9$ \\
\hline
\end{tabular}

1) 肺転移結節数中央值

の腫瘍は比較的厚い線維性被膜に被われ周囲組織への 浸潤傾向を示さず，また中心壞死を認めた（図 $3 \mathrm{~A}$ ). 他方, orthotopic site に形成された腫瘍の組織型は原 腫瘍のそれと非常によく類似した腎細胞癌, clear cell common type が主体であった（図 3B)，また肺転移巣 
図 5 抗ヒト collagenase type IV 抗体を用いたヌー ドマウス腫瘍の免疫組織像：A) 皮下 (ectopic site）を腫瘍を抗ヒト $72 \mathrm{kda}$ collagenase type IV 抗 体で染色，B）腎被膜下 (orthotopic site) 腫瘍を抗 ヒト $72 \mathrm{kda}$ collagenase type IV 抗体で染色 (X 100 ).

腎被膜下に形成された腫瘍では皮下に形成された腫 瘍に比べ72kda collagenase type IV の産生が増強 していた.
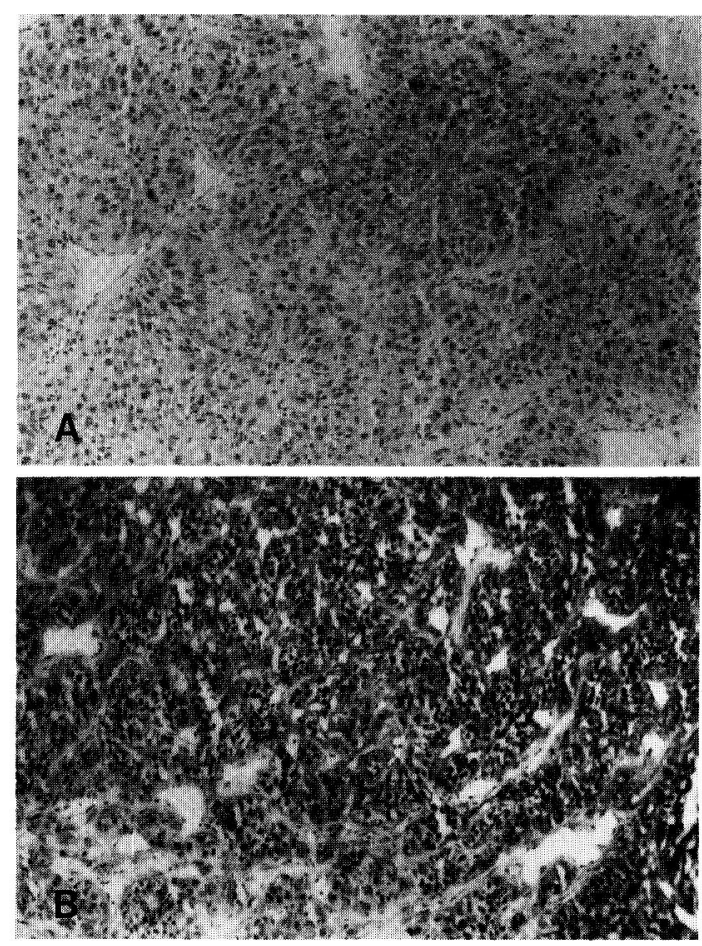

は orthotopic siteの腫瘍と類似した組織型を示して おり，また被膜を有せず macrophage の浸潤を認めた (data は示さず).

4. ヌードマウスに形成された腫瘍の免疫組織学的 検討

Ectopic site（皮下）に形成された腫瘍は比較的大型 の血管が柾に増生しているのに対し, orthotopic site (腎被膜下)に形成された腫瘍は多数の小血管が密に増 生していた(図 4A，B). また腎被膜下に形成された腫 瘍では皮下に形成された腫瘍に比べ72kda および92 $\mathrm{kda}$, collagenase type IV の発現が共に強く認められ た（図 5A，B，92kda, collagenase type IV の data は示さず).

\section{考察}

癌細胞は heterogenityであることはよく知られて

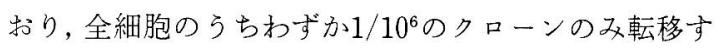
る能力を有しているとされる、癌が転移巣を形成する には幾つかの step を経なければならない(4)5). 即ら，1） 癌細胞が局所 (原発巣) で増殖すること，2）癌細胞が 原発栄から周囲組織への浸潤すること,3）癌細胞が脈 管内皮細胞を破壞し脈管内への侵入すること,4）脈管 内に侵入した癌細胞が脈管内での血流, リンパ流等の 機械的外力に打ちかつこと,5）血小板等により癌細胞 が凝集し標的藏器で trapされること，6）癌細胞が標 的臓器での脈管外への浸潤すること,7) 癌細胞が標的 蔵器での増殖すること, これら諸因子がすべて満たさ れてはじめて転移が形成される。1889年, Paget (は6)癌 が転移巣を形成するためには癌細胞（seed）のみなら ず転移を形成する標的葴器 (soil) が重要であると提唱 した，彼の仮説は後に前立腺癌は骨，大腸癌は訮，腎 癌は肺に最も転移するといら事実により正当化されて いる。また Fidler らは，癌細胞がその原発巣より浸潤 し転移を形成するには，癌細胞自身の特性，例えば癌 細胞の遊走能, collagenase type IVなどの extracellular matrix degradate enzyme の産生能などの他に 癌細胞が移植あるいは播種された部位の宿主側の環境 因子が重要であると報告した ${ }^{78)}$. 例えば彼らは, ヌー ドマウスの皮下にヒト大腸癌細胞を移植すると, 皮下 に形成された腫瘍は決して転移浸潤傾向を示さないの に対し，同一細胞を結腸壁に移植すると同部位に形成 された腫瘍は高率に肝転移を形成する8)，また同様に ヒト乳癌細胞を乳房組織へ9), 前立腺癌細胞を前立腺 へ移植すれば高率に転移を形成することを示した ${ }^{10)}$. 今回, 我々は新しい樹立したヒト堅細胞癌培湌細胞 （KG-2）をヌードマウスの皮下および腎被膜下へ移植 しその造腫瘍能と転移能を検討した。本腫瘍は ectopic siteである皮下抢よび orthotopic site である 腎被膜下における造腫瘍能に差を認めないが，皮下に 形成された腫瘍は決して転移浸潤傾向を示さないのに 対し，腎被膜下に形成された腫瘍周团組織へ浸潤する と共に高率に肺転移をきたした。しかも興味深いのは 腎被膜下に形成された腫瘍は原腫瘍と非常に類似した 組織像を呈しているのに対し，皮下に形成されたもの の組織像は原腫瘍のそれとおおいに異なっていた。こ のことは，腎細胞癌細胞 (KG-2)にとって ectopic site である皮下と orthotopic siteである腎被膜下ではそ れぞれの部位で増殖するのに適したクローンのみ増殖 したことを示しており，移植部位における宿主由来の 異なった増殖囚子が関与していることを強く示唆して 
いる。

近年, extracellular matrix degradate enzyme $の$ 一種である collagenase type IVは extracellular matrix および血管内皮細胞基底膜の主な構成成分で ある collagen type IVを破壊するため本酵素活性の 発現の程度と転移浸潤能とはよく相関することが示さ れている2(11) 13). 今回の我々の検討に打いて, ヌードマ ウスょり摘出した腫瘍を抗ヒト $72 \mathrm{kda}$ および $92 \mathrm{kda}$ collagenase type IV 抗体あるいは血管壁の collagen type IV と反応する抗マウス collagen type IV 抗体を 用い免疫組織学染色を施行したところ，腎被膜下に形 成された腫瘍では皮下に形成された腫瘍に比べ非常に 強く72kda おょび92kda collagenase type IV の発現 と多数の新生血管の増生が認められた.このことから， 同一癌細胞でもヌードマウスの移植部位によって癌細 胞のもつ collagenase type IV の発現と腫瘍新生血管 の増生に差が生じ，その結果として腎被膜下に形成さ れた腫瘍で周囲組織および血管内への浸潤傾向を有 し，肺に転移をきたすと推定された。

これらの事実は腎細胞癌（KG-2）では orthotopic site（腎被膜下）では KG-2細胞のもつ collagenase type IV の産生が host 側の何らかの因子により促進 され，他方 ectopic site（皮下）では抑制されているこ とを示している。更に orthotopic site（腎被膜下）に 形成された腫瘍では小血管が密に増生していたのに対 して ectopic site（皮下）に形成された腫瘍では比較的 大きな血管が柾に形成されていたこともこれらの両者 の腫瘍の転移能に大きく関与しているものと思われ る。これら collagenase type IVの発現および腫瘍内 血管新生に影響を及ぼす host 側の因子につき現在検 討を加えている.

\section{結 語}

1）新しくヒト腎細胞癌細胞(KG-2)を樹立すると共 に本細胞を用いたヌードマウス転移モデルを作成し た。

2）KG-2細胞の転移形成には orthotopic site（腎被 膜下）への移植が必要である.

3）KG-2細胞を orthotopic site（腎被膜下）に移植 し形成された腫瘍は ectopic site（皮下）に形成した腫 瘍に比べ collagenase type IV の発現が強く, 腫瘍内 新生血管が豊富であった。これらの相異が両者の転移 能の差異に大きく関与していると思われた.

4）Ectopic site（皮下）および orthotopic site（腎 被膜下）に形成された腫瘍の collagenase type IV の
発現, および腫瘍新生血管の増生に影響を与える host 側の因子につき検討中である。

5）本転移モデルはヒト腎細胞癌の転移機序の解明 に有用であると思われた。

\section{文献}

1) 腎癌取扱い規約：日本泌尿器科学会・日本病理 学・日本医学放射線学会編, 金原出版, 東京, 1983 ,

2) Naito, S., von Eschenbach, A.C. and Fidler, I.J. Different growth patterns and biologic behavior of human renal cell carcinoma implanted into different organs of nude mice. J. Natl. Cancer Inst., $78: 377-385,1987$.

3) Nakajima, M., Morikawa, K., Fabra, A., Bucana, C.D. and Fidler, I.J.: Influence of organ environment on extracellular matrix degradative activity and metastasis of human colon carcinoma cells. J. Natl. Cancer Inst., 82 : 1890-1898, 1990.

4) Nicolson, G.L. : Cancer metastasis ; tumor cell and host organ properties important in metastasis to specific secondary sites. Biochem. Biophys. Acta, 948, 175-224, 1988.

5) Poste, G. and Fidler, I.J.: The pathogenesis of cancer metastasis. Nature, 283, 139-146, 1979.

6) Paget, S.: The distribution of secondary growths in cancer of the breast. Lancet 1 , $571-573,1889$.

7) Fider, I.J.; Orthotopic implanttion of human colon carcinoma into nude mice for the biology and therapy of cancer metastasis. Cancer Metastasis Rev., 10, 229-243, 1991.

8) Morikawa, K., Walker, S.M., Jessup, J.M. and Fidler, I.J. : In vivo selection of highly metastatic cells from surgical specimens of different human colon carcinomas implanted into nude mice. Cancer Res., 48, 1943-1948, 1988.

9) Price, J.E., Polyzos, A., Zhang, R.D. and Daniels, L.M. : Tumorigenicity and metastasis of human breast carcinoma cell line in nude mice. Cancer Res., 50, 717-721, 1990.

10) Stephenson, R.A., Dinney, C.P.N., Gohji, K., Ordonez, N.G., Killion, J.J. and Fidler, I.J. : Metastatic model for human prostate cancer using orthotopic implanttion in nude mice. J. Natl. Cancer Inst., 84, 951-957, 1992.

11) Liotta, L.A., Tryggvason, K., Garbisa, S., Hart, I.R., Foltz, C.M. and Shafie, S.: Metastatic potential correlates with enzymatic degradation of basement membrane collagen. Nature, 248, 67-68, 1980.

12) Nakajima, M., Welch, D.R., Belloni, P.N. and 
Nicolson, G.L.: Degradation of basement membrane type IV collagen and lung subendotherial matrix by rat mammary adenocarcinoma cell clones of differing metastatic potentials. Cancer Res., 47, 4869-4876, 1987.

13) Morikawa, K., Walker, S.M., Nakajima, M.,
Pathak, S., Jessup, J.M. and Fidler, I.J. : Influence of organ environment on the growth, selection and metastasis of human colon carcinoma cells in nude mice. Cancer Res., 48, 6863-6871, 1988.

（1992年12月 4 日受理） 